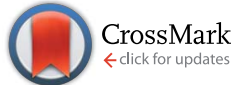

Cite this: RSC Adv., 2017, 7, 4510

Received 13th November 2016 Accepted 19th December 2016

DOI: $10.1039 / c 6 r a 26746 g$

www.rsc.org/advances

\section{Ring opening polymerization of lactides and lactones by multimetallic alkyl zinc complexes derived from the acids $\mathrm{Ph}_{2} \mathrm{C}(\mathrm{X}) \mathrm{CO}_{2} \mathrm{H}(\mathrm{X}=\mathrm{OH}$, $\left.\mathrm{NH}_{2}\right) \dagger$}

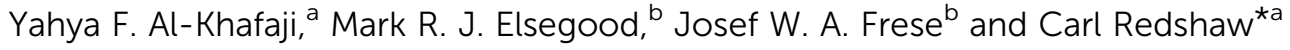

The reaction of the dialkylzinc reagents $\mathrm{R}_{2} \mathrm{Zn}$ with the acids $2,2-\mathrm{Ph}_{2} \mathrm{C}(\mathrm{X})\left(\mathrm{CO}_{2} \mathrm{H}\right)$, where $\mathrm{X}=\mathrm{NH}_{2}, \mathrm{OH}$, i.e. $2,2^{\prime}$-diphenylglycine $(\mathrm{dpgH})$ or benzilic acid $\left(\mathrm{benz}_{2}\right)$, in toluene at reflux temperature afforded the tetranuclear ring complexes $[R Z n(d p g)]_{4}$, where $\mathrm{R}=\mathrm{Me}(1)$, Et (2), $2-\mathrm{CF}_{3} \mathrm{C}_{6} \mathrm{H}_{4}$ (3), and 2,4,6- $\mathrm{F}_{3} \mathrm{C}_{6} \mathrm{H}_{2}$ (4); complex 2 has been previously reported. The crystal structures of $1 \cdot(2 \mathrm{MeCN}), 3$ and $4 \cdot\left(4\left(\mathrm{C}_{7} \mathrm{H}_{8}\right)\right.$. $\left.1.59\left(\mathrm{H}_{2} \mathrm{O}\right)\right)$ are reported, along with that of the intermediate compound $\left(2-\mathrm{CF}_{3} \mathrm{C}_{6} \mathrm{H}_{4}\right)_{3} \mathrm{~B} \cdot \mathrm{MeCN}$ and the known compound $\left[\mathrm{ZnCl}_{2}(\mathrm{NCMe})_{2}\right]$. Complexes 1-4, together with the known complex $\left[(\mathrm{ZnEt})_{3}(\mathrm{ZnL})_{3}(\text { benz })_{3}\right](5 ; \mathrm{L}=\mathrm{MeCN})$, have been screened, in the absence of benzyl alcohol, for their potential to act as catalysts for the ring opening polymerization (ROP) of $\varepsilon$-caprolactone $(\varepsilon-C L), \delta$ valerolactone $(\delta-\mathrm{VL})$ and rac-lactide (rac-LA); the co-polymerization of $\varepsilon-C L$ with rac-LA was also studied. Complexes 3 and 4 bearing fluorinated aryls at zinc were found to afford the highest activities.
\end{abstract}

\section{Introduction}

The last decade has seen a continued interest in the development of catalytic systems for the production of biodegradable polymers, typically via the ring opening polymerization (ROP) of cyclic esters. ${ }^{1}$ This interest stems from the use of polycaprolactone (PCL) and polylactic acid (PLA) in the packaging and medical (as implants) industries. ${ }^{2}$ Furthermore, given the differing properties that can be associated with both PCL and PLA, there is interest in $\varepsilon$-Cl/LA copolymers of varying compositions; low molecular weight $\varepsilon$-Cl/LA copolymers have been employed as bio-adhesives. ${ }^{3}$

In terms of control, as well as judicious choice of metal centre, it has become clear that the ligand set can also play a pivotal role in determining the catalytic behaviour of the ROP system. Chelating $\mathrm{N}, \mathrm{O}$ - or $\mathrm{O}, \mathrm{O}$-ligand sets have shown great potential. ${ }^{1}$ With this in mind, we have been investigating the use of acids containing the motif $\mathrm{Ph}_{2} \mathrm{C}(\mathrm{X})$, where $\mathrm{X}=\mathrm{OH}, \mathrm{NH}_{2}$, i.e. benzilic acid $(\mathrm{X}=\mathrm{OH})$ and diphenylglycine $\left(\mathrm{X}=\mathrm{NH}_{2}\right)$, which is known to impart crystallinity. ${ }^{4}$ A search of the CSD revealed 33 hits for the $\mathrm{Ph}_{2} \mathrm{C}(\mathrm{N})\left(\mathrm{CO}_{2}\right)$ moiety, the majority of which were organic in nature; a chart of the non-organic structures is given

${ }^{a}$ School of Mathematics and Physical Sciences, The University of Hull, Cottingham Rd, Hull, HU6 7RX, UK. E-mail: C.Redshaw@hull.ac.uk

${ }^{b}$ Chemistry Department, Loughborough University, Loughborough, Leicestershire, LE11 3TU, UK

$\dagger$ Electronic supplementary information (ESI) available. CCDC 1516751-1516755. For ESI and crystallographic data in CIF or other electronic format see DOI: 10.1039/c6ra26746g in the ESI (Chart S1 $\dagger$ ). ${ }^{5}$ We have recently screened a number of these systems for the ROP of cyclic esters, in particular alkylaluminium species, ${ }^{6}$ and a number of complexes comprising $\mathrm{Li}_{x} \mathrm{O}_{y}$ rings and ladders ${ }^{7}$ have revealed reasonable activity. Given that zinc complexes have also shown promise over the years as ROP pre-catalysts, ${ }^{8}$ we have now turned our attention to alkylzinc complexes incorporating the $\mathrm{Ph}_{2} \mathrm{C}(\mathrm{X})$ motif. We have previously published a number of intriguing molecular structures derived from these acids and alkylzinc and aluminium reagents including tetra-, hexa- and octanuclear ring systems, ${ }^{9}$ however the ROP capability of such systems was not examined. Herein, we extend the family of complexes available by employing zinc reagents where $\mathrm{R}=\mathrm{Me}$ or a fluorinated aryl group (see Scheme 1), and assess their ability as catalysts towards the ROP of $\varepsilon$-caprolactone $(\varepsilon-\mathrm{CL}), \delta$-valerolactone $(\delta$-VL) and $r a c$-lactide ( $r a c$-LA); the co-polymerization of $\varepsilon$-CL with racLA has also been studied.

\section{Results and discussion}

Use of 2,2'-diphenylglycine (dpgH)

Using our previously published procedure, ${ }^{9 \boldsymbol{b}}$ we here reacted $\mathrm{Me}_{2} \mathrm{Zn}$ (2.1 equiv.) with dgpH and following work-up, the resulting white solid was characterized via elemental analysis, IR spectroscopy with $\nu \mathrm{NH}$ stretches at 3345 and $3233 \mathrm{~cm}^{-1}$, and by ${ }^{1} \mathrm{H}$ NMR spectroscopy with doublets at 3.02 and $5.79 \mathrm{ppm}$ assigned to exo and endo $\mathrm{NH}_{2}$ protons respectively. Single crystals suitable for X-ray diffraction were grown from a saturated solution of acetonitrile. The molecular structure of $\mathbf{1} \cdot 2 \mathrm{MeCN}$ is 


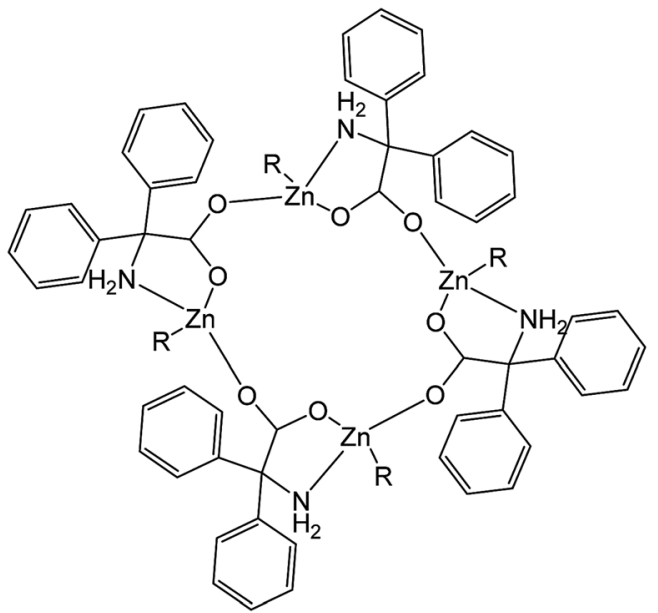

$\mathrm{R}=\mathrm{Me}$ (1), Et (2), $\mathrm{C}_{6} \mathrm{H}_{4} \mathrm{CF}_{3}-2$ (3),

$\mathrm{C}_{6} \mathrm{H}_{2}(\mathrm{~F})_{3}-2,4,6(4)$

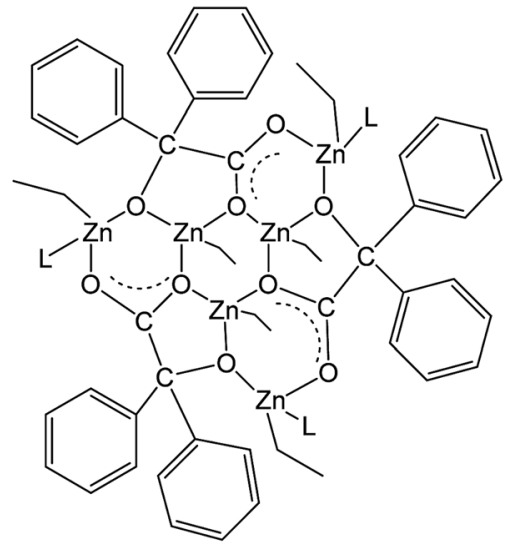

$\mathbf{5}, \mathrm{L}=\mathrm{MeCN}$

Scheme 1 Organozinc complexes 1-5 studied herein.

shown in Fig. 1 (for an alternative view of the core of the molecule see Fig. S1, ESI $\dagger$ ), with selected bond lengths and angles given in the caption. As for the ethyl derivative $[\mathrm{EtZn}(\mathrm{dpg})]_{4}(2)$, each zinc is four coordinate with a $\mathrm{Ph}_{2} \mathrm{C}\left(\mathrm{NH}_{2}\right)-\mathrm{CO}_{2}$ ligand binding in $\mathrm{N}, \mathrm{O}$ fashion, whilst the other oxygen of this ligand binds to an adjacent zinc. The result is a 16-membered ring adopting an updown-up-down conformation, in which the carboxylates all bind in anti/syn fashion. One of the $\mathrm{NH}_{2}$ groups is involved in an

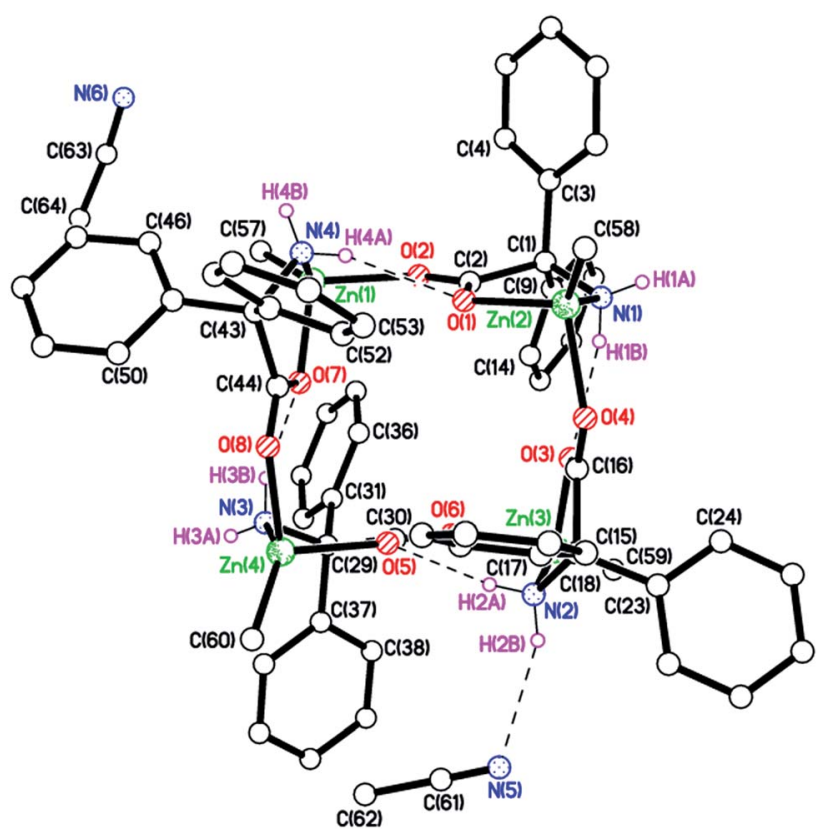

Fig. 1 Molecular structure of 1 . Selected bond lengths $(\AA)$ and angles $\left(^{\circ}\right): \mathrm{Zn}(1)-\mathrm{O}(2)$ 2.017(2), $\mathrm{Zn}(1)-\mathrm{O}(7)$ 2.056(3), Zn(1)-N(4) 2.090(3) $\mathrm{Zn}(1)-C(57)$ 1.958(4), $\mathrm{Zn}(2)-\mathrm{O}(1) 2.090(3), \mathrm{Zn}(2)-O(4) 2.029(3), \mathrm{Zn}(2)-$ $\mathrm{N}(1) 2.083(3), \mathrm{Zn}(2)-\mathrm{C}(58)$ 1.937(5); $\mathrm{Zn}(1)-\mathrm{O}(2)-\mathrm{C}(2)$ 132.0(2), Zn(1)$\mathrm{O}(7)-\mathrm{C}(44)$ 117.1(2), $\mathrm{Zn}(1)-\mathrm{N}(4)-\mathrm{C}(43)$ 109.2(2), $\mathrm{Zn}(2)-\mathrm{O}(1)-\mathrm{C}(2)$ 115.7(2), $\mathrm{Zn}(2)-\mathrm{O}(4)-\mathrm{C}(16)$ 130.5(2), $\mathrm{Zn}(2)-\mathrm{N}(1)-\mathrm{C}(1)$ 110.4(2) intramolecular $\mathrm{H}$-bond to a neighbouring dpg carboxylate oxygen, whilst another forms an H-bond to an acetonitrile. In terms of packing, there are two channels containing acetonitriles that run parallel to $b$ and $c$ (see Fig. S2, ESI $\dagger$ ).

When the reagent [EtZnCl ${ }^{10}$ was reacted with $\mathrm{dpgH}$, the only crystalline material isolated following work-up was the known compound $\left[\mathrm{ZnCl}_{2}(\mathrm{NCMe})_{2}\right]$. Although the structure has been previously reported, both of the previous data collections were conducted at room temperature and neither refinement included $\mathrm{H}$ atoms. ${ }^{11}$ We have thus presented our improved, low temperature structure of $\left[\mathrm{ZnCl}_{2}(\mathrm{NCMe})_{2}\right]$ in the ESI (Fig. S3 and $\mathrm{S} 4 \dagger)$, which reveals a layer structure.

Similar use of $\left(2-\mathrm{CF}_{3} \mathrm{C}_{6} \mathrm{H}_{4}\right)_{2} \mathrm{Zn}$ led to the isolation of [(2$\left.\left.\mathrm{CF}_{3} \mathrm{C}_{6} \mathrm{H}_{4}\right) \mathrm{Zn}(\mathrm{dpg})\right]_{4}$ (3) in good yield (68\%). The product was characterized by IR spectroscopy with $\nu \mathrm{NH}$ stretches at 3306, 3242 and $3172 \mathrm{~cm}^{-1}$, and by ${ }^{1} \mathrm{H}$ NMR spectroscopy with doublets at 3.02 and $5.79 \mathrm{ppm}$ assigned to exo and endo $\mathrm{NH}_{2}$ protons respectively. Crystals suitable for X-ray diffraction were grown from a saturated solution of acetonitrile at ambient temperature. The structure, shown in Fig. 2 (for an alternative view see Fig. S5, ESI $\dagger$ ), was crystallographically challenging in that it was both merohedrally twinned via the twin law 010100 00-1 (major component $54(2) \%$ ), and racemically twinned (Flack parameter $0.472(2)$ ). A structure solution was only possible after temporary 'de-twinning' of the reflection data. The full data and the twin law were then used for the structure refinement.

One quarter of the $\mathrm{Zn}_{4}$ complex is unique, and the zinc centres are arranged up-down-up-down with $\overline{4}$ symmetry in the macrocycle. There is no solvent of crystallization; the packing is shown in Fig. S6, ESI. $\dagger$

Extending the methodology to the use of $\left(2,4,6-\mathrm{F}_{3}-\mathrm{C}_{6} \mathrm{H}_{2}\right)_{2} \mathrm{Zn}$ led to the isolation of the complex $\left[\left(2,4,6-\mathrm{F}_{3}-\mathrm{C}_{6} \mathrm{H}_{2}\right) \mathrm{Zn}(\mathrm{dpg})\right]_{4}(4)$ in moderate yield ( $c a .40 \%$ ), for which the IR spectrum contained $\nu \mathrm{NH}$ stretches at 3318 and $3172 \mathrm{~cm}^{-1}$, and the ${ }^{1} \mathrm{H}$ NMR spectrum doublets at 3.43 and $5.38 \mathrm{ppm}$ assigned to exo and endo $\mathrm{NH}_{2}$ protons respectively. Single crystals were grown from a saturated 
Table 1 ROP screening using 1-5

\begin{tabular}{|c|c|c|c|c|c|c|c|c|}
\hline Run & Cat & Monomer & [Monomer] : Cat : BnOH & Time & $\operatorname{Conv}^{a}(\%)$ & $M_{\mathrm{n}, \mathrm{GPC}}{ }^{b}$ & $M_{\mathrm{n}, \mathrm{Cal}}^{c}$ & $\mathrm{PDI}^{d}$ \\
\hline 1 & 1 & $\varepsilon-\mathrm{CL}$ & $150: 1: 0$ & 1 & 74 & 9580 & 12670 & 1.37 \\
\hline 2 & 2 & $\varepsilon-\mathrm{CL}$ & $150: 1: 0$ & 1 & 82 & 10600 & 14040 & 1.31 \\
\hline 4 & 4 & $\varepsilon-\mathrm{CL}$ & $150: 1: 0$ & 1 & 92 & 12900 & 15750 & 1.31 \\
\hline 5 & 5 & $\varepsilon-\mathrm{CL}$ & $150: 1: 0$ & 1 & 84 & 10800 & 14380 & 1.10 \\
\hline 6 & 1 & $r a c$-LA & $100: 1: 0$ & 12 & 55 & 4550 & 7930 & 1.88 \\
\hline 9 & 4 & $r a c$-LA & $100: 1: 0$ & 12 & 67 & 6150 & 9660 & 1.23 \\
\hline 10 & 5 & $r a c$-LA & $100: 1: 0$ & 12 & 61 & 5970 & 8790 & 1.27 \\
\hline 11 & 1 & $\delta$-VL & $100: 1: 0$ & 24 & 42 & 1300 & 4210 & 2.12 \\
\hline 12 & 2 & $\delta$-VL & $100: 1: 0$ & 24 & 50 & 1810 & 5010 & 2.18 \\
\hline 13 & 3 & $\delta$-VL & $100: 1: 0$ & 24 & 54 & 2810 & 5410 & 1.14 \\
\hline 14 & 4 & $\delta$-VL & $100: 1: 0$ & 24 & 58 & 2670 & 5810 & 1.13 \\
\hline
\end{tabular}

${ }^{a}$ Determined by ${ }^{1} \mathrm{H}$ NMR spectroscopy. ${ }^{b} M_{\mathrm{n}, \mathrm{GPC}}$ values corrected considering Mark-Houwink factors (0.56 poly( $(\varepsilon$-caprolactone), 0.58 (polylactide)) from polystyrene standards in THF. ${ }^{c}$ Calculated from $\left([\text { monomer }]_{0} /[\text { cat }]_{0}\right) \times$ conv $(\%) \times$ monomer molecular weight. ${ }^{d}$ From GPC.

solution of toluene at ambient temperature. The molecular structure is shown in Fig. 3 (for an alternative view see Fig. S7, $\mathrm{ESI}^{\dagger}$ ), with selected bond lengths and angles given in the caption. The asymmetric unit comprises one quarter of $\left[\left(2,4,6-\mathrm{F}_{3}-\mathrm{C}_{6} \mathrm{H}_{2}\right)\right.$ $\mathrm{Zn}(\mathrm{dpg})]_{4} \cdot 4\left(\mathrm{C}_{7} \mathrm{H}_{8}\right) \cdot 1.59\left(\mathrm{H}_{2} \mathrm{O}\right)$ given the $\overline{4}$ symmetry. One of the $\mathrm{NH}$ protons $\mathrm{H}$-bonds to the $\mathrm{Zn}$-bound $\mathrm{O}(1)$ carboxylate atom, while the other forms a $\mathrm{C}-\mathrm{H} \cdots \pi$ interaction to the toluene of crystallisation with the distance from the ring centroid to the $\mathrm{H}$ atom being $2.549 \AA$. The core structure is very similar to that in described in 1 above. In the packing of 4 (see Fig. S8, ESI $\dagger$ ), there are some weak intermolecular $\mathrm{C}-\mathrm{H} \cdots \mathrm{F}$ interactions between 2,4,6- $\mathrm{F}_{3}-\mathrm{C}_{6} \mathrm{H}_{2}$ groups and the toluene molecule, with the toluene bridging two 2,4,6- $\mathrm{F}_{3}-\mathrm{C}_{6} \mathrm{H}_{2}$ groups.

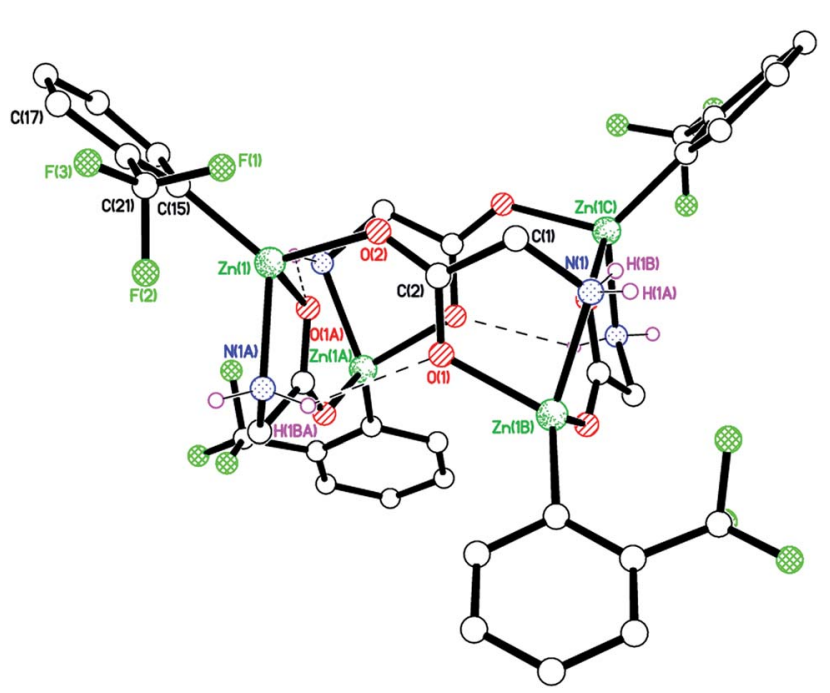

Fig. 2 Molecular structure of 3 with dpg Ph groups omitted for clarity. Selected bond lengths $(\AA)$ and angles $\left(^{\circ}\right)$ : Zn(1)-O(2) 1.993(7), Zn(1)$\mathrm{O}(1 \mathrm{~A}) 2.049(6), \mathrm{Zn}(1)-\mathrm{N}(1 \mathrm{~A}) 2.091(8), \mathrm{Zn}(1)-\mathrm{C}(15)$ 1.966(10), Zn(1B)$\mathrm{O}(1)$ 2.048(6), Zn(1B)-N(1) 2.091(8) Zn(1)-C(15)-C(16) 125.9(9), Zn(1)$\mathrm{C}(15)-\mathrm{C}(20)$ 118.5(8), $\mathrm{Zn}(1 \mathrm{~B})-\mathrm{O}(1)-\mathrm{C}(2)$ 116.6(6), Zn(1B) $-\mathrm{N}(1)-\mathrm{C}(1)$ 109.7(5). Symmetry codes: $A=y+1 / 2,-x+1 / 2,-z+1 / 2 ; B=-y+$ $1 / 2, x-1 / 2,-z+1 / 2$.

\section{Use of benzilic acid}

For comparative studies, the previously reported complex $\left[(\mathrm{ZnEt})_{3}(\mathrm{ZnL})_{3}(\text { benz })_{3}\right](\mathbf{5} ; \mathrm{L}=\mathrm{MeCN})$ has also been prepared. ${ }^{{ }^{\boldsymbol{b}}}$

\section{Molecular structure of tris(boron) intermediate}

During the preparation of $\left(2-\mathrm{CF}_{3} \mathrm{C}_{6} \mathrm{H}_{4}\right)_{2} \mathrm{Zn}$, we isolated and structurally characterized the acetonitrile solvate of $\left(2-\mathrm{CF}_{3} \mathrm{C}_{6}\right.$ $\left.\mathrm{H}_{4}\right)_{3} \mathrm{~B}(\mathrm{NCMe}$ ). This intermediate was prepared using a modification of the synthesis of $\mathrm{B}\left(\mathrm{C}_{6} \mathrm{~F}_{5}\right)_{3}$ reported by Lancaster; ${ }^{\mathbf{1 2}}$ subsequent treatment with $\mathrm{Et}_{2} \mathrm{Zn}$ affords $\left(\mathrm{C}_{6} \mathrm{~F}_{5}\right)_{2} \mathrm{Zn}$, i.e. $\mathrm{C}_{6} \mathrm{~F}_{5}$ transfer. However, herein we limited the scale of this preparation $(<5 \mathrm{~g})$ and conducted it behind a safety shield given the

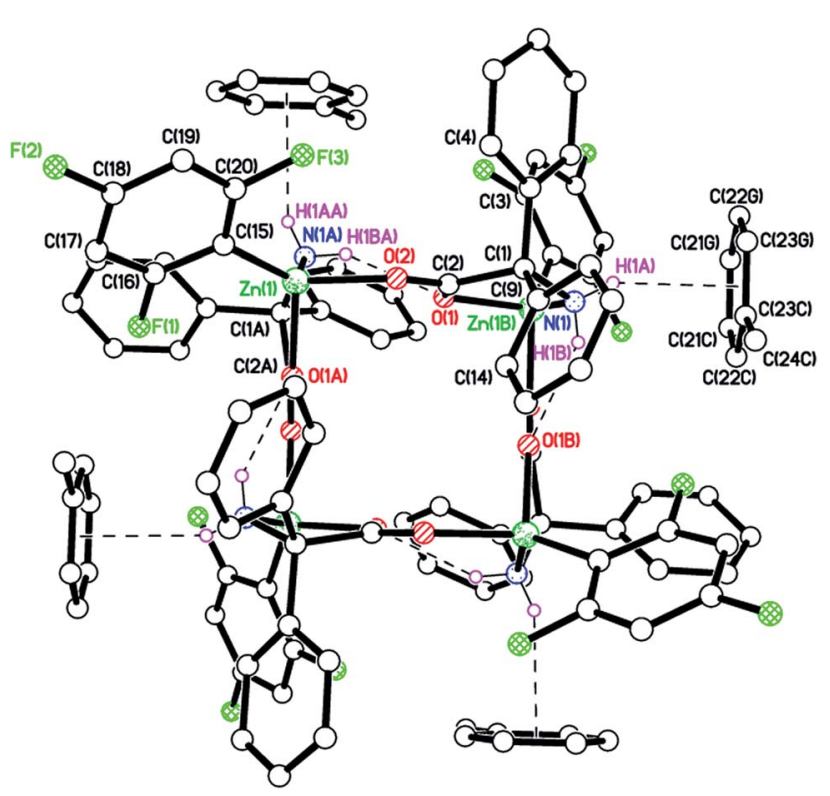

Fig. 3 Molecular structure of 4 . Selected bond lengths $(\AA)$ and angles ( ): $\mathrm{Zn}(1)-\mathrm{O}(2) 2.008(2), \mathrm{Zn}(1)-\mathrm{O}(1 \mathrm{~A}) 2.0304(19), \mathrm{Zn}(1)-\mathrm{N}(1 \mathrm{~A}) 2.065(2)$, $\mathrm{Zn}(1)-\mathrm{C}(15)$ 1.965(3); $\mathrm{Zn}(1)-\mathrm{O}(2)-\mathrm{C}(2)$ 124.62(18), $\mathrm{Zn}(1 \mathrm{~B})-\mathrm{N}(1)-\mathrm{C}(1)$ 111.26(16). Symmetry codes: $A=-y+1, x,-z+1 ; B=y,-x+1,-z+1$. 


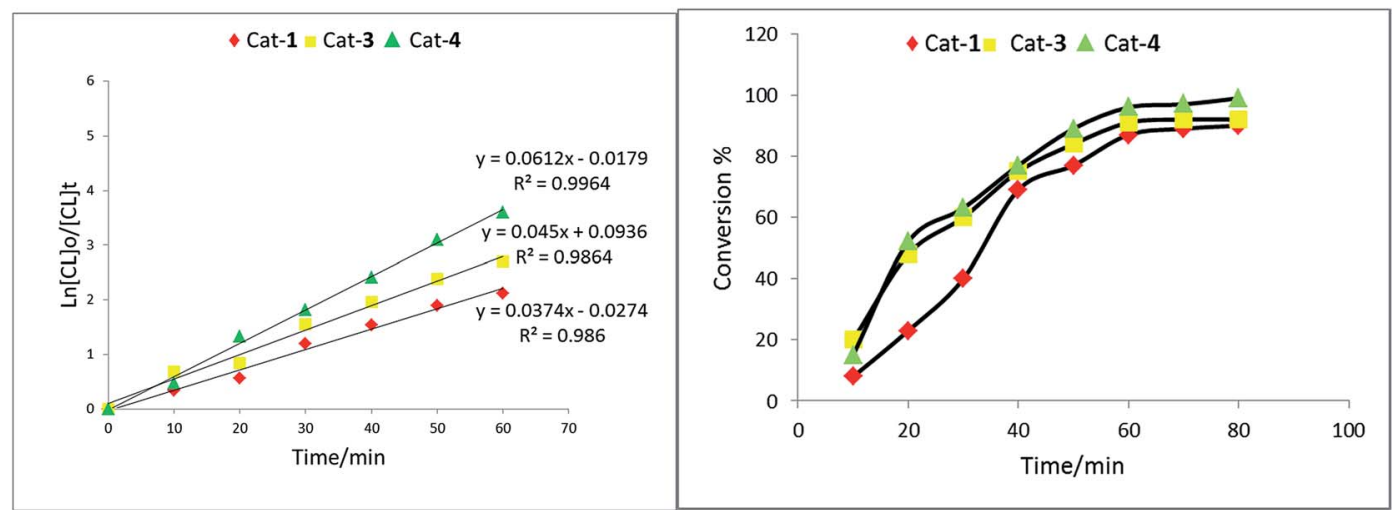

Fig. 4 Left: Plot of $\ln [C L]_{0} /[C L]_{t}$ vs. time using complex 1, 3 and 4; right: relationship between conversion and time for the polymerization of $C L$.

precedent for explosions when using halogeno(trifluoromethyl) benzenes for Grignard synthesis. ${ }^{\mathbf{1 3}}$ We note that Ashley and coworkers have employed i-PrMgCl for metal halogen exchange with 1-bromo-3,5-bis(trifluoromethyl)benzene, which was subsequently reacted with $\mathrm{BF}_{3} \cdot \mathrm{OEt}_{2}$ to afford tris[3,5-bis(trifluoromethyl)phenyl]borane. ${ }^{\mathbf{1 4}}$

The molecular structure of $\left(2-\mathrm{CF}_{3} \mathrm{C}_{6} \mathrm{H}_{4}\right)_{3} \mathrm{~B}(\mathrm{NCMe})$ is shown in Fig. $\mathrm{S} 9, \dagger$ with selected bond lengths and angles given in the caption. The three phenyl groups are twisted by 43.5, 45.6 and $36.4^{\circ}$, forming a propeller-like orientation. The acetonitrile-free complex has previously been characterized, which possessed near $C_{3}$ symmetry and twist angles of $45.6,49.3$ and 52.9 , reflecting the increased space available around the 3-coordinate B centre. ${ }^{15}$

\section{Ring opening polymerization}

Homopolymerization of $\varepsilon$-caprolactone, rac-lactide and $\delta$ valerolactone. Complexes 1-5 have been screened for their ability to ring open polymerize (ROP) $\varepsilon$-caprolactone rac-lactide or $\delta$-valerolactone in the absence of benzyl alcohol $(\mathrm{BnOH})$ at $110{ }^{\circ} \mathrm{C}$. Compound 4 was used to optimize the polymerization conditions and the results are summarized in Table S1 (see ESI $\dagger$ ). The observations suggested that the best results could be obtained when using a molar ratio for [monomer] : [4] of $150: 1$ for $\varepsilon$-CL or $100: 1$ for $r a c$-LA and $\delta$-VL at a temperature of $110^{\circ} \mathrm{C}$ over $1 \mathrm{~h}$ for $\varepsilon$-CL or $12 \mathrm{~h}$ or $24 \mathrm{~h}$ for rac-LA and $\delta$-VL, respectively.
Under these conditions, each of 1-5 was screened for the ROP of $\varepsilon$-CL, rac-LA and $\delta$-VL; the results are presented in Table 1.

For $\boldsymbol{\varepsilon}$-CL. The relationship between the monomer mole ratios and the number of average molecular weight values (e.g. for 4 in Fig. S10†) is near linear indicating that this is a living polymerization process, whilst the polydispersity in the range 1.10 to 1.40 indicates that the process was well controlled. The activity associated with the complexes bearing a fluorinated aryl group, namely $\mathbf{3}$ and $\mathbf{4}$ was higher than those possessing an alkyl group (complexes 1, 2 and 5); observed molecular weights $\left(M_{\mathrm{n}}\right)$ followed the same trend. Nomura and coworkers have previously noted enhanced catalytic performances when employing fluorinated imino substituents in phenoxyimine aluminium catalysts for the ROP of $\varepsilon-C L{ }^{16}$ Furthermore, a firstorder dependence on the $\varepsilon$-CL concentration was observed for the polymerization rate for the ROP of $\varepsilon$-CL (Fig. 4 left). From the $K_{\text {obs }}$ values, it is evident that the catalytic activity follows the order $\mathbf{4}>\mathbf{3}>\mathbf{1}$, again suggesting that the presence of the fluorinated aryl group led to an improvement in the catalytic performance (Fig. 4, right), with $>60 \% \varepsilon$-CL conversion achieved over $30 \mathrm{~min}$. The ${ }^{1} \mathrm{H}$ and ${ }^{13} \mathrm{C}$ NMR spectra (Fig. S11 and S12 $\dagger$ ) of the PCL indicated that the end groups were $\mathrm{CH}_{2} \mathrm{OH}$ and there was no evidence for cyclic PCL. The MALDI-TOF spectrum (Fig. $\mathrm{S} 13 \dagger$ ) of the PCL revealed peaks separated by 114 mass units. There was also evidence of a second, albeit minor, population.

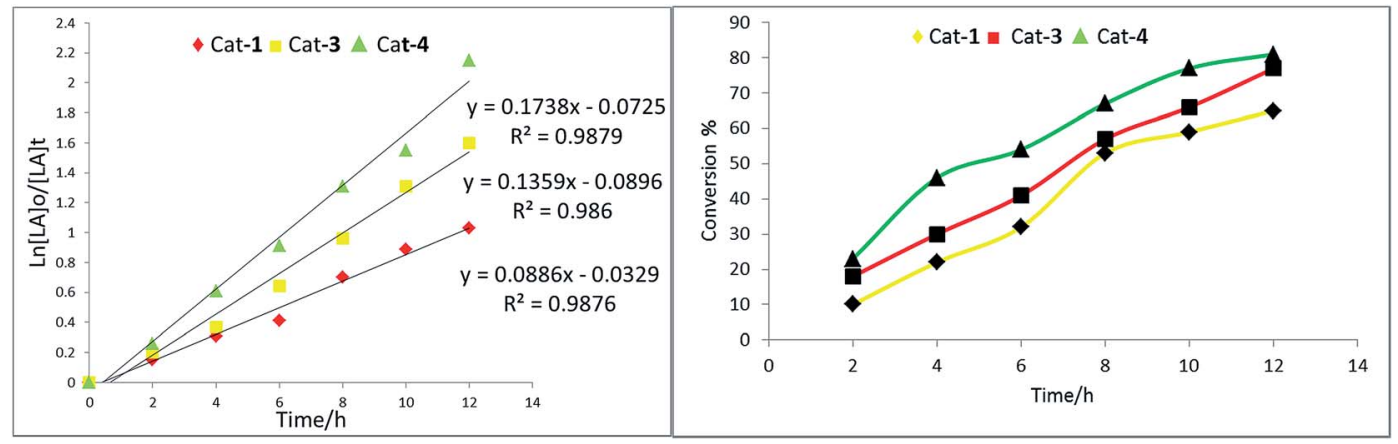

Fig. 5 Left: Plot of $\ln [r a c-L A]_{0} /[r a c-L A]_{t}$ vs. time using 1, 3 and 4; right: relationship between conversion and time of polymerization. 
Table 2 Synthesis of diblock co-polymers from cyclic ester monomers $(\varepsilon-C L+r a c-L A)$

\begin{tabular}{llllll}
\hline $\operatorname{Run}^{a}$ & Cat & CL $: \mathrm{LA}^{b}$ & Yield & $M_{\mathrm{n}}{ }^{c}$ & PDI $^{d}$ \\
\hline 1 & $\mathbf{1}$ & $62: 38$ & 65 & 5310 & 1.09 \\
2 & 2 & $60: 40$ & 72 & 2900 & 1.12 \\
3 & $\mathbf{3}$ & $53: 47$ & 77 & 5160 & 1.19 \\
4 & $\mathbf{4}$ & $55: 45$ & 58 & 2210 & 1.25 \\
5 & $\mathbf{5}$ & $56: 44$ & 69 & 3590 & 1.08 \\
$6^{e}$ & $\mathbf{4}$ & - & - & - & -
\end{tabular}

${ }^{a}$ Optimum conditions: $1 \mathrm{~h} \varepsilon$-CL $110{ }^{\circ} \mathrm{C} / 12 \mathrm{~h}$ rac-LA $110{ }^{\circ} \mathrm{C},(150[\varepsilon-$ $\mathrm{CL}]: 150$ [rac-LA] : [cat] $]$. ${ }^{b}$ Ratio of CL to LA observed in the copolymer by ${ }^{1} \mathrm{H}$ NMR spectroscopy. ${ }^{c} M_{\mathrm{n}}$ values were determined by GPC in THF vs. PS standards and were corrected with a MarkHouwink factor $\left(M_{\mathrm{n}, \mathrm{GPC}} \times 0.56 \times \% \mathrm{PCL}+M_{\mathrm{n}, \mathrm{GPC}} \times 0.58 \times \% \mathrm{Pr}\right.$-LA $)$. ${ }^{d}$ PDI were determined by GPC. ${ }^{e}$ Reverse addition (i.e. rac-LA added first).

For rac-LA. Screening of 1-5 (see Table 1 runs 6-10) indicated that the complexes bearing the fluorinated aryl groups again performed better than those bearing the alkyl groups at zinc. According to the entries (11-15, Table S1†), there is a linear relationship between the monomer mole ratios and the number of average molecular weight values (Fig. S14 $\dagger$ ) with PDI [1.19-1.51] that suggest a living polymerization process and some degree of control. The plot shown in Fig. 5 (left) reveals a first order dependence on [rac-LA], whilst the $K_{\mathrm{obs}}$ values indicated the activity order $4>3>1$, with 40 to $50 \%$ raclactide conversion achieved over 6 h for 3 and 4 (Fig. 5, right). The ${ }^{1} \mathrm{H}$ NMR and ${ }^{13} \mathrm{C}$ NMR spectra of the PLA (Fig. S15 and $\mathrm{S} 16 \dagger)$ are consistent with non-cyclic products. The MALDI-TOF spectrum of the polycaprolactone (Fig. S17†) contained a series of peaks separated by half a lactide unit (72.0); there was also a second minor population. Homonuclear decoupled and $2 \mathrm{D} J$-resolved ${ }^{1} \mathrm{H}$ NMR spectra of the resulting polymers revealed that these systems gave atactic PLA (Fig. S18-S21, ESI $\dagger) .{ }^{17}$

For $\delta$-VL. The ROP of $\delta$-valerolactone catalyzed by complexes 1-5 was also investigated; results are presented in Table 1 (runs 11-15). As for both the other monomers screened herein, high conversions and polymer molecular weights were achieved when using the systems bearing the fluorinated aryl groups at zinc. Systems 3 and 4 also exhibited better control (PDIs 1.13 and 1.14) than the other systems employed for the ROP of $\delta$ valerolactone.

The plot of $[\delta$-VL $] /[4]$ (Fig. S22 $\dagger$ ) is near linear. From the ${ }^{1} \mathrm{H}$ NMR spectra of the PVL (Fig. S23 $\dagger$ ), the peak at $\delta 3.62$ revealed the presence of a $\mathrm{CH}_{2} \mathrm{OH}$ end group. In general, it was evident that the ROP of $\delta$-VL required more robust conditions than were required for $\varepsilon-C L$, which is consistent with the thermodynamic parameters for these lactones. ${ }^{18}$

Co-polymerization of $\varepsilon$-caprolactone and rac-lactide. The copolymerisation of $\varepsilon$-CL with rac-LA was studied using complexes 1 to 5 at $110{ }^{\circ} \mathrm{C}$, and the results are summarized in Table 2. Yields of the co-polymers were in the range $58-77 \%$. However, unlike for the homo-polymerizations, there was no obvious advantage in using the fluorinated systems in terms of activity, though they afforded slightly higher polylactide content (as observed by ${ }^{1} \mathrm{H}$ NMR spectra, e.g. see Fig. S24, ESI $\dagger$ ). The ${ }^{13} \mathrm{C}$ NMR spectra of the co-polymers (e.g. Fig. S25, ESI $\dagger$ ) exhibited both carbonyl signals at 169 and 174 ppm due to the polycaprolactone and polylactide components, respectively. Thermal analysis (by DSC) of the co-polymers revealed (see Fig. S26, ESI $\dagger$ ) two peaks at about $50.7{ }^{\circ} \mathrm{C}$ and $178{ }^{\circ} \mathrm{C}$, which is similar to other reported CL/LA co-polymers. ${ }^{19}$ The reverse addition of monomers resulted in little or no polymerization.

In conclusion, we have synthesised a series of alkylzinc complexes of formula $[\mathrm{RZn}(\mathrm{dpg})]_{4}$, where $\mathrm{R}=\mathrm{Me}(\mathbf{1})$, Et (2), 2$\mathrm{CF}_{3} \mathrm{C}_{6} \mathrm{H}_{4}$ (3), 2,4,6- $\mathrm{F}_{3} \mathrm{C}_{6} \mathrm{H}_{2}$ (4) and dpg is derived from $\mathrm{Ph}_{2} \mathrm{C}(\mathrm{X})$ $\mathrm{CO}_{2} \mathrm{H}(\mathrm{dpgH})$. In each complex, the core structure is very similar, with the zinc macrocycle adopting an up-down-updown conformation. Complexes 1-4 and the known benzilic acid (benzH $)_{2}$-derived complex $\left[(\mathrm{ZnEt})_{3}(\mathrm{ZnL})_{3}(\text { benz) })_{3}\right](5)$ were found to be active for the ROP of $\varepsilon-\mathrm{Cl}$, rac-LA and $\delta$-VL, without benzyl alcohol present. Complexes 3 and $\mathbf{4}$, bearing fluorinated aryls at zinc, were found to afford the highest activities. All complexes were also capable of affording copolymers via sequential addition of the monomers $\varepsilon$-Cl and rac-LA.

\section{Experimental}

All manipulations were carried out under an atmosphere of nitrogen using standard Schlenk line and cannula techniques or a conventional $\mathrm{N}_{2}$ filled glove box. Solvents were refluxed over the appropriate drying agents, and distilled and degassed prior to use. Elemental analyses were performed at London Metropolitan University and the University of Hull. NMR spectra were recorded on a Varian VXR $400 \mathrm{~S}$ spectrometer at $400 \mathrm{MHz}$, a Gemini at $300 \mathrm{MHz}$ or a Bruker DPX300 spectrometer at 300 $\mathrm{MHz}\left({ }^{1} \mathrm{H}\right)$ and $75.5 \mathrm{MHz}\left({ }^{13} \mathrm{C}\right)$ at $298 \mathrm{~K}$; chemical shifts are referenced to the residual protio impurity of the deuterated solvent. IR spectra (KBr discs) were recorded on a Perkin-Elmer 577 or 457 grating spectrophotometer. DSC analyses of polymer samples were performed on a TA Instruments DSC Q 1000. Matrix Assisted Laser Desorption/Ionization-Time Of Flight (MALDI-TOF) mass spectrometry was performed on Bruker autoflex III smart beam in linear mode. MALDI-TOF mass spectra were acquired by averaging at least 100 laser shots. 2,5Dihydroxylbenzoic acid was used as matrix and tetrahydrofuran as solvent. Sodium chloride was dissolved in methanol and used as the ionizing agent. Samples were prepared by mixing 20 $\mu \mathrm{L}$ of polymer solution in tetrahydrofuran $\left(2 \mathrm{mg} \mathrm{mL}^{-1}\right)$ with 20 $\mu \mathrm{L}$ of matrix solution $\left(10 \mathrm{mg} \mathrm{mL}^{-1}\right)$ and $1 \mu \mathrm{L}$ of a solution of ionizing agent $\left(1 \mathrm{mg} \mathrm{mL}{ }^{-1}\right)$. Then $1 \mathrm{~mL}$ of these mixtures was deposited on a target plate and allowed to dry in air at room temperature. The dialkylzinc complexes were prepared either via the Chisholm method involving addition of lithium salts to $\mathrm{ZnCl}_{2}$ or via the Bochmann method whereby trisaryl(boron) reagents are used as aryl transfer agents with either $\mathrm{Me}_{2} \mathrm{Zn}$ or $\mathrm{Et}_{2} \mathrm{Zn}^{.{ }^{12,20}}[\mathrm{EtZn}(\mathrm{dpg})]_{4}$ (2) was prepared by our previously reported procedure. ${ }^{9 b}$ All other chemicals were obtained commercially and were used as received unless stated otherwise. 


\section{Synthesis of $[\mathrm{MeZn}(\mathrm{dpg})]_{4} \cdot 2 \mathrm{MeCN}(1 \cdot 2 \mathrm{MeCN})$}

A solution of dimethylzinc (9.25 mL, $9.25 \mathrm{mmol}, 1 \mathrm{M}$ in toluene) was added at room temperature to a solution of diphenylglycine $(1.00 \mathrm{~g}, 4.40 \mathrm{mmol})$ in toluene $(30 \mathrm{~mL})$. The resulting solution was heated under reflux for $12 \mathrm{~h}$, volatiles were removed in vacuo, and the residue was extracted into warm acetonitrile (30 $\mathrm{mL})$. Prolonged standing at $0{ }^{\circ} \mathrm{C}$ afforded colourless crystals of 1. Yield $0.98 \mathrm{~g}, 68.1 \%$. Elemental analysis calculated for $\mathrm{C}_{60^{-}}$ $\mathrm{H}_{60} \mathrm{~N}_{4} \mathrm{O}_{8} \mathrm{Zn}_{4} \cdot 2\left(\mathrm{C}_{2} \mathrm{H}_{3} \mathrm{~N}\right): \mathrm{C}, 58.68 ; \mathrm{H}, 5.04 ; \mathrm{N}, 6.44 \%$. Found: $\mathrm{C}$, 58.67; H, 4.91; N, 6.58\%. IR (nujol null, $\mathrm{KBr}, \mathrm{cm}^{-1}$ ): 3345 (m), 3233 (bw), 2955 (s), 2923 (s), 2853 (s), 2358 (w), 1659 (w), 1644 (m), 1602 (s), 1491 (w), 1460 (s), 1378 (s), 1260 (s), $1211(\mathrm{w}), 1152$ (w), $1135(\mathrm{w}), 1108(\mathrm{w}), 1079(\mathrm{~m}), 1042(\mathrm{~m}), 1022(\mathrm{~s}), 945(\mathrm{~m}), 808$ (s), $769(\mathrm{~m}), 730(\mathrm{~m}), 701(\mathrm{~s}), 730(\mathrm{~m}), 671(\mathrm{~m}), 636(\mathrm{w}), 624(\mathrm{w})$, $615(\mathrm{~m}), 571(\mathrm{w}), 535(\mathrm{w}), 500(\mathrm{w}), 473(\mathrm{w})$. MS (ES, positive mode): $m / z 1036\left[\mathrm{M}-\mathrm{Ph}_{2} \mathrm{C}\left(\mathrm{NH}_{2}\right) \mathrm{CO}_{2} \mathrm{H}-3 \mathrm{Me}\right], 971\left[\mathrm{M}-\mathrm{Ph}_{2} \mathrm{C}\left(\mathrm{NH}_{2}\right)\right.$ $\mathrm{CO}_{2} \mathrm{H}-\mathrm{ZnMe}-2 \mathrm{Me}$ ], 744 [M-2Ph $\mathrm{P}_{2} \mathrm{C}\left(\mathrm{NH}_{2}\right) \mathrm{CO}_{2} \mathrm{H}-\mathrm{ZnMe}-2 \mathrm{Me}$ ], 517 $\left[\mathrm{M}-3 \mathrm{Ph}_{2} \mathrm{C}\left(\mathrm{NH}_{2}\right) \mathrm{CO}_{2} \mathrm{H}-\mathrm{ZnMe}-2 \mathrm{Me}\right] .{ }^{1} \mathrm{H} \mathrm{NMR}\left(\mathrm{CDCl}_{3}, 400 \mathrm{MHz}\right)$ $\delta: 7.02-7.60(3 \times \mathrm{m}, 40 \mathrm{H}, \operatorname{aryl} H), 5.79\left(\mathrm{~d}, 4 \mathrm{H},{ }^{2} J_{\mathrm{HH}}=10.8\right.$, endo$\left.\mathrm{NH}_{2}\right), 3.02\left(\mathrm{~d}, 4 \mathrm{H},{ }^{2} J_{\mathrm{HH}}=10.8\right.$, exo-N $\left.H_{2}\right), 2.35(\mathrm{~s}, 6 \mathrm{H}, M e \mathrm{CN}), 0.22$ $\left(\mathrm{s}, 6 \mathrm{H}, \mathrm{Zn}-\mathrm{CH}_{3}\right), 0.07\left(\mathrm{~s}, 6 \mathrm{H}, \mathrm{Zn}-\mathrm{CH}_{3}\right)$.

\section{Synthesis of $\left[\left(2-\mathrm{CF}_{3} \mathrm{C}_{6} \mathrm{H}_{4}\right) \mathrm{Zn}(\mathrm{dpg})\right]_{4}(3)$}

As for 1, but using $\left(2-\mathrm{CF}_{3} \mathrm{C}_{6} \mathrm{H}_{4}\right)_{2} \mathrm{Zn}(3.28 \mathrm{~g}, 9.24 \mathrm{mmol})$ and diphenylglycine $(1.00 \mathrm{~g}, 4.40 \mathrm{mmol})$. Prolonged standing at $0{ }^{\circ} \mathrm{C}$ afforded colourless crystals of 3 . Yield $1.14 \mathrm{~g}, 59.0 \%$. Elemental analysis calculated for $\mathrm{C}_{84} \mathrm{H}_{56} \mathrm{~F}_{12} \mathrm{~N}_{4} \mathrm{O}_{8} \mathrm{Zn}_{4} \cdot 0.2\left(\mathrm{C}_{2} \mathrm{H}_{3} \mathrm{~N}\right)$ : C, 57.70; H, 3.22; N, 3.35\%. Found: C, 57.91; H, 3.28; N, 3.31\%. IR (nujol null, KBr, cm ${ }^{-1}$ ): 3306 (w), 3242 (bw), $3175(\mathrm{w}), 1661$ (s), 1644 (s), 1608 (w), 1493 (w), 1343 (s), 1262 (s), 1195 (w), 1160 (w), 1131 (m), 1090 (m), 1079 (s), 1051 (m), 1040 (m), 1026 (s), 803 (s), 773 (w), $760(\mathrm{w}), 744(\mathrm{w}), 731(\mathrm{w}), 694(\mathrm{~s}), 673(\mathrm{w}), 615$ (s). MS (ES, positive mode): $\mathrm{m} / \mathrm{z} 1519\left[\mathrm{M}-\mathrm{Ph}_{2} \mathrm{C}\left(\mathrm{NH}_{2}\right) \mathrm{CO}_{2} \mathrm{H}\right], 1373$ [M$\left.\mathrm{Ph}_{2} \mathrm{C}\left(\mathrm{NH}_{2}\right) \mathrm{CO}_{2} \mathrm{H}-\mathrm{Ar}-\mathrm{CF}_{3}\right] .{ }^{1} \mathrm{H}$ NMR $\left(\mathrm{CDCl}_{3}, 400 \mathrm{MHz}\right) \delta$ : 7.57$7.02(4 \times \mathrm{m}, 56 \mathrm{H}, \operatorname{aryl} H), 5.79\left(\mathrm{~d}, 4 \mathrm{H},{ }^{2} J_{\mathrm{HH}}=10.7 \mathrm{~Hz}\right.$, endo $\left.-\mathrm{NH}_{2}\right)$, $3.02\left(\mathrm{~d}, 4 \mathrm{H},{ }^{2} J_{\mathrm{HH}}=10.7 \mathrm{~Hz}\right.$, exo- $\left.\mathrm{NH}_{2}\right), 2.35(\mathrm{~s}, \mathrm{H}, \mathrm{MeCN}) \cdot{ }^{19} \mathrm{~F}$ NMR $\left(\mathrm{dmsO}_{\mathrm{d} 6}\right) \delta:-61.09 .{ }^{19} \mathrm{~F}$ NMR $\left(\mathrm{dmsO}_{\mathrm{d} 6}\right) \delta:-61.09$.

\section{Synthesis of $\left[\left(2,4,6-\mathrm{F}_{3} \mathrm{C}_{6} \mathrm{H}_{2}\right) \mathrm{Zn}(\mathrm{dpg})\right]_{4} \cdot 4\left(\mathrm{C}_{7} \mathrm{H}_{8}\right) \cdot\left(1.59 \mathrm{H}_{2} \mathrm{O}\right)$ $\left(4 \cdot 4\left(\mathrm{C}_{7} \mathrm{H}_{8}\right) \cdot\left(1.59 \mathrm{H}_{2} \mathrm{O}\right)\right)$}

As for 1, but using $\left(2,4,6-\mathrm{FC}_{6} \mathrm{H}_{2}\right){ }_{2} \mathrm{Zn}(3.03 \mathrm{~g} 9.24 \mathrm{mmol})$ and diphenylglycine $(1.00 \mathrm{~g} 4.40 \mathrm{mmol})$. Prolonged standing of a saturated toluene solution at $0{ }^{\circ} \mathrm{C}$ afforded colourless 4 . Yield $1.14 \mathrm{~g}, 54.0 \%$. Sample dried in vacuo for number of hours; $3.58 \mathrm{C}_{7} \mathrm{H}_{8} \cdot 1.59 \mathrm{H}_{2} \mathrm{O}$. Elemental analysis calculated for $\mathrm{C}_{66} \mathrm{H}_{40^{-}}$ $\mathrm{F}_{12} \mathrm{~N}_{4} \mathrm{O}_{8} \mathrm{Zn}_{4} \cdot 0.42\left(\mathrm{C}_{7} \mathrm{H}_{8}\right): \mathrm{C}, 53.53 ; \mathrm{H}, 2.80 ; \mathrm{N}, 3.62 \%$. Found: $\mathrm{C}$, 52.91; H, 2.79; N, 3.62\%. IR (nujol null, KBr, $\mathrm{cm}^{-1}$ ): 3318 (s), 3172 (w), 2725 (w), 1660 (m), 1605 (s), 1587 (m), 1460 (s), 1377 (s), $1305(\mathrm{w}), 1260(\mathrm{~m}), 1148(\mathrm{~m}), 1101(\mathrm{~m}), 1042(\mathrm{w}), 1022(\mathrm{~m})$, $990(\mathrm{~m}), 839(\mathrm{w}), 802(\mathrm{~m}), 774(\mathrm{~m}), 743(\mathrm{~m}), 728(\mathrm{~m}), 698(\mathrm{~m}), 631$ (w), $609(\mathrm{w}), 512(\mathrm{w}), 472(\mathrm{w})$. MS (ES, positive mode): $\mathrm{m} / \mathrm{z} 1147$ $\left[\mathrm{M}-0.42\right.$ toluene- $\mathrm{Ph}_{2} \mathrm{C}\left(\mathrm{NH}_{2}\right) \mathrm{CO}_{2} \mathrm{H}-$ aryl- $\left.\mathrm{F}_{3}\right], \quad 920 \quad[\mathrm{M}-0.42$ toluene- $\mathrm{Ph}_{2} \mathrm{C}\left(\mathrm{NH}_{2}\right) \mathrm{CO}_{2} \mathrm{H}$-aryl- $\left.\mathrm{F}_{3}-\mathrm{Ph}_{2} \mathrm{C}\left(\mathrm{NH}_{2}\right) \mathrm{CO}_{2} \mathrm{H}\right] ;{ }^{1} \mathrm{H} \quad \mathrm{NMR}$ $\left(\mathrm{CDCl}_{3}, 400 \mathrm{MHz}\right) \delta: 7.46-7.12(4 \times \mathrm{m}, 48 \mathrm{H}$, aryl $\mathrm{H}+0.42$ $\left.C_{6} H_{5} \mathrm{CH}_{3}\right), 5.38\left(\mathrm{~d}, 4 \mathrm{H},{ }^{2} J_{\mathrm{HH}}=11.2 \mathrm{~Hz}\right.$, endo- $\left.\mathrm{NH}_{2}\right), 3.43(\mathrm{~d}, 4 \mathrm{H}$,
${ }^{2} J_{\mathrm{HH}}=11.2 \mathrm{~Hz}$, exo- $\left.\mathrm{NH}_{2}\right), 2.35\left(\mathrm{~s}, 1.2 \mathrm{H}, 0.42 \mathrm{C}_{6} \mathrm{H}_{5} \mathrm{CH}_{3}\right) .{ }^{19} \mathrm{~F} \mathrm{NMR}$ $\left(\mathrm{dmso}_{\mathrm{d} 6}\right) \delta:-83.91(\mathrm{~s}, 4 \mathrm{~F}, o-\mathrm{F}),-84.37(\mathrm{~s}, 4 \mathrm{~F}, o-\mathrm{F}),-107.29(\mathrm{~s}$, $1 \mathrm{~F}, p-\mathrm{F}),-112.81(\mathrm{~s}, 2 \mathrm{~F}, p-\mathrm{F}),-114.78(\mathrm{~s}, 1 \mathrm{~F}, p-\mathrm{F})$.

\section{Synthesis of $\left(2-\mathrm{CF}_{3} \mathrm{C}_{6} \mathrm{H}_{4}\right)_{3} \mathrm{~B} \cdot \mathrm{MeCN}$}

2-Bromobenzotrifluoride $(5.60 \mathrm{~mL}, 0.041 \mathrm{~mol})$ was slowly added to $\mathrm{Mg}$ turnings $(1.00 \mathrm{~g}, 0.041 \mathrm{~mol})$ in diethyl ether $(150 \mathrm{~mL})$ at $0{ }^{\circ} \mathrm{C}$ and the system was stirred for $2 \mathrm{~h}$. The Grignard solution was then added to $\mathrm{BF}_{3} \cdot \mathrm{Et}_{2} \mathrm{O}(1.60 \mathrm{~mL}, 0.013 \mathrm{~mol})$ in toluene $(100 \mathrm{~mL})$ at $0{ }^{\circ} \mathrm{C}$, and the system was slowly allowed to warm to ambient temperature. The diethyl ether was then removed under vacuo, and the system was heated to $100{ }^{\circ} \mathrm{C}$ on a water bath for $1 \mathrm{~h}$. Following removal of volatiles, the residue was extracted into hexane $(150 \mathrm{~mL})$. Removal of the hexane and crystallization from acetonitrile $(80 \mathrm{~mL})$ afforded $\left(2-\mathrm{CF}_{3} \mathrm{C}_{6}\right.$ $\left.\mathrm{H}_{4}\right)_{3} \mathrm{~B} \cdot \mathrm{MeCN}$. Yield $4.60 \mathrm{~g}, 79.8 \%$. IR (nujol null, $\mathrm{KBr}, \mathrm{cm}^{-1}$ ): 2922 (bw), 2345 (w), 2341 (w), 1954 (w), 1661 (m), 1596 (m), 1462 (s), 1376 (s), 1313 (s), 1258 (m), 1164 (m), 1142 (m), 1060 (w), 1032 (m), $999(\mathrm{~m}), 899(\mathrm{~s}), 801(\mathrm{~m}), 771(\mathrm{~m}), 669(\mathrm{~m}), 655(\mathrm{w}), 645$ (w), $616(\mathrm{w}), 581(\mathrm{w}), 497(\mathrm{w}), 441(\mathrm{w})$. MS (ES, positive mode): $\mathrm{m} /$ $z 446$ [M-MeCN], 300 [M-MeCN-Ar-CF 3 ]. ${ }^{1} \mathrm{H}$ NMR $\left(\mathrm{CDCl}_{3}, 400\right.$ $\mathrm{MHz}) \delta: 7.72-7.22(4 \times \mathrm{m}, 12 \mathrm{H}, \operatorname{aryl} H), 1.99(\mathrm{~s}, 3 \mathrm{H}, \mathrm{MeCN}) .{ }^{11} \mathrm{~B}$ $\mathrm{NMR}\left(\mathrm{CDCl}_{3}, 400 \mathrm{MHz}\right) \delta: 70.13$ (bs).

\section{Ring opening polymerization procedure}

Typical polymerization procedures are as follows. A mixture of monomer (3.44 mmol of $\varepsilon$-caprolactone), $2.29 \mathrm{mmol}$ rac-lactide or (2.29 mmol $\delta$-valerolactone) and catalyst $1(0.02 \mathrm{mmol})$ were added into a Schlenk tube at room temperature under nitrogen protection and toluene $(5 \mathrm{~mL})$ was added to the reaction mixture. The reaction mixture was then placed into an oil bath pre-heated to the required temperature, and the solution was stirred for the prescribed time. The polymerization mixture was then quenched by addition of an excess of glacial acetic acid (0.2 $\mathrm{mL}$ ) into the solution, and the resultant solution was then poured into methanol $(200 \mathrm{~mL})$. The resultant polymer was then collected on filter paper and was dried in vacuo.

\section{Copolymerization procedure}

Co-polymerizations were conducted by adding $\varepsilon$-CL $(3.44 \mathrm{mmol})$ to the catalyst $(0.02 \mathrm{mmol})$ in toluene $(10 \mathrm{~mL})$ pre-heated to $110{ }^{\circ} \mathrm{C}$ and stirring for $1 \mathrm{~h}$, and then adding rac-lactide (3.44 $\mathrm{mmol}$ ) and stirring for a further $12 \mathrm{~h}$. The reaction mixture was quenched by addition $(200 \mathrm{~mL})$ of methanol. The precipitate was collected and dried in vacuo.

\section{X-ray crystallography}

Diffraction data were collected on a Bruker APEX 2 CCD diffractometer and were corrected for absorption and $\mathrm{LP}$ effects. ${ }^{21}$ Further details are provided in Table 3. Structures were solved by direct methods \{charge flipping for $\mathbf{4} \cdot 4\left(\mathrm{C}_{7} \mathrm{H}_{8}\right)$. $\left.1.59\left(\mathrm{H}_{2} \mathrm{O}\right)\right\}$ and refined by full matrix least squares methods. ${ }^{22}$ $\mathrm{N}-\mathrm{H}$ distances were restrained for structures $\mathbf{1} \cdot 2 \mathrm{MeCN}$ and $4 \cdot 4\left(\mathrm{C}_{7} \mathrm{H}_{8}\right) \cdot 1.59\left(\mathrm{H}_{2} \mathrm{O}\right)$. The structure 3 was refined as merohedrally twinned via the twin law 010100 00-1 (major component 
$54(2) \%$ ), and racemically twinned (Flack parameter 0.472(2)). A structure solution was only possible after temporary 'de-twinning' of the reflection data. The full data and the twin law were then used for the structure refinement. For $\mathbf{4} \cdot 4\left(\mathrm{C}_{7} \mathrm{H}_{8}\right)$. $1.59\left(\mathrm{H}_{2} \mathrm{O}\right)$ the toluene lies on a symmetry element and the methyl group was 50/50 disordered over two positions as a result. There was also a significant residual electron density peak close to an aromatic ring $\mathrm{H}$ atom. This was modelled as a partial water molecule with $39.7(9) \%$ occupancy with $\mathrm{H}$ atoms not located.

Table 3 Crystallographic data for complexes $1 \cdot 2 \mathrm{MeCN}, 3,4$ and $\left(2-\mathrm{CF}_{3} \mathrm{C}_{6} \mathrm{H}_{4}\right)_{3} \mathrm{~B}(\mathrm{NCMe}) \cdot \mathrm{MeCN}$

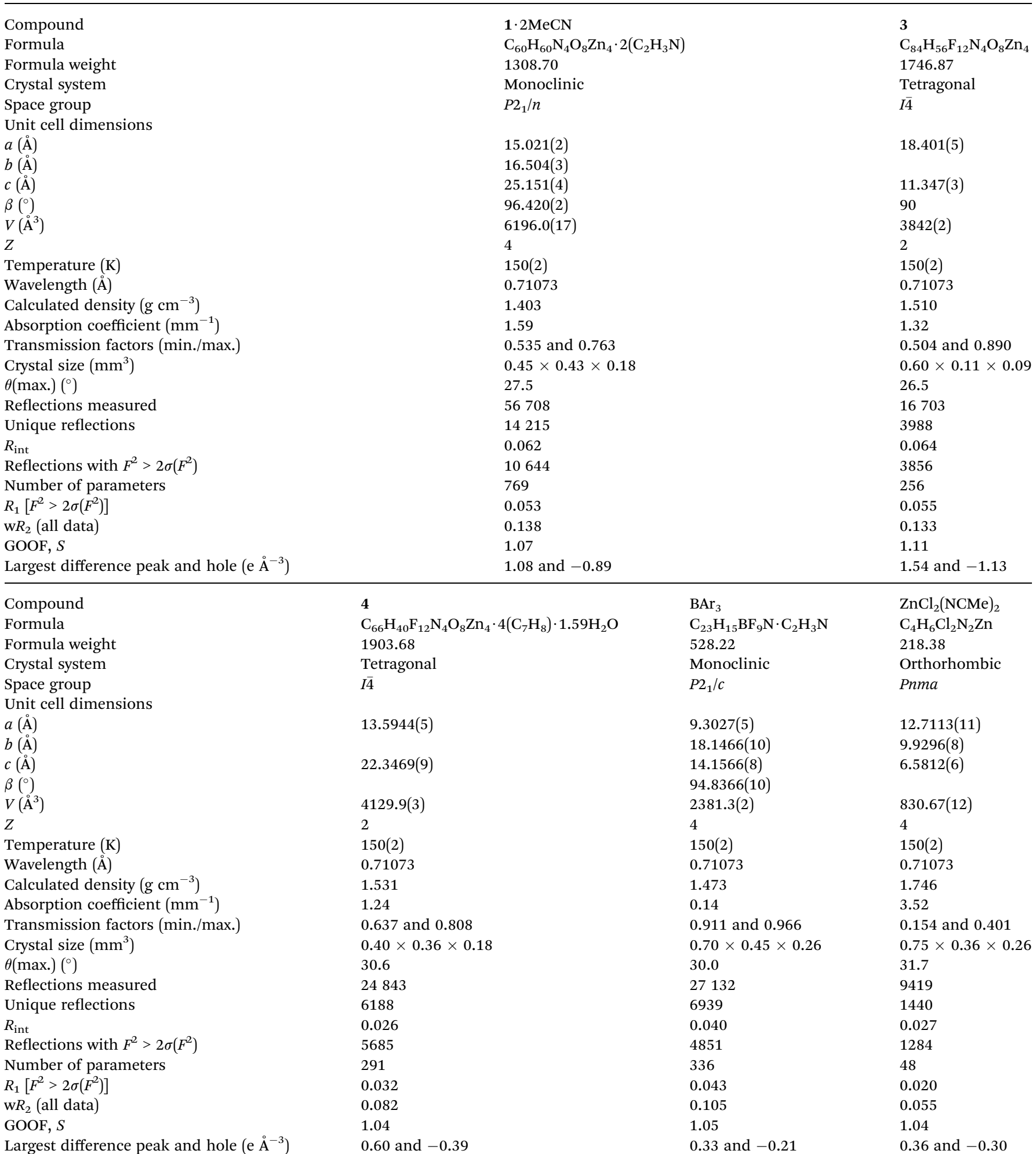




\section{Acknowledgements}

The National Mass Spectrometry Service at Swansea and Dr Kevin Welham (University of Hull) are both thanked for mass spectrometry data. We wish to acknowledge the use of the EPSRC's Chemical Database Service hosted by the RSC. The higher committee for education development in Iraq and the EPSRC are thanked for financial support.

\section{References}

1 For recent reviews see: (a) A. Corma, S. Iborra and A. Velty, Chem. Rev., 2007, 107, 2411; (b) C. K. Williams and M. A. Hillmyer, Polym. Rev., 2008, 48, 1; (c) E. S. Place, J. H. George, C. K. Williams and M. H. Stevens, Chem. Soc. Rev., 2009, 38, 1139; (d) M. Labet and W. Thielemans, Chem. Soc. Rev., 2009, 38, 3484; (e) A. Arbaoui and C. Redshaw, Polym. Chem., 2010, 1, 801; (f) X. Rong and C. Chunxia, Progress in Chemistry, 2012, 24, 1519.

2 (a) R. E. Drumright, P. R. Gruber and D. E. Henton, Adv. Mater., 2000, 12, 1841-1846; (b) M. A. Woodruff and D. W. Hutmacher, Prog. Polym. Sci., 2010, 35, 1217-1256; (c) A. L. Sisson, D. Ekinci and A. Lendlein, Polymer, 2013, 54, 4333-4350.

3 S. Sriputtirat, W. Boonkong, S. Pengprecha, A. Petsom and N. Thongchul, Adv. Chem. Eng. Sci., 2012, 2, 15.

4 M. Braun, Angew. Chem., 1996, 108, 565; Angew. Chem. Int. Ed., 1996, 35, 519.

5 F. H. Allen, Acta Crystallogr., Sect. B: Struct. Sci., 2002, 58, 380-388.

6 X. Wang, K.-Q. Zhao, S. Mo, Y. F. Al-Khafaji, T. J. Prior, M. R. J. Elsegood and C. Redshaw, unpublished results.

7 Y. F. Al-Khafaji, T. J. Prior, L. Horsburgh, M. R. J. Elsegood and C. Redshaw, unpublished results.

8 See for example, C. K. Williams, L. E. Breyfogle, S. K. Choi, W. Nam, V. G. Young, M. A. Hillmyer and W. B. Tolman, J. Am. Chem. Soc., 2003, 125, 11350-11359 and references therein.
9 (a) C. Redshaw, M. R. J. Elsegood and K. E. Holmes, Angew. Chem., Int. Ed., 2005, 44, 1884-1887; (b) C. Redshaw and M. R. J. Elsegood, Angew. Chem., Int. Ed., 2007, 46, 74537457.

10 A. Guerrero, D. L. Hughes and M. Bochmann, Organometallics, 2006, 25, 1525-1527.

11 (a) I. V. Isakov and Z. V. Zvonkova, Dokl. Akad. Nauk SSSR, 1962, 145, 808; (b) V. K. Bel'sky, N. R. Stetsova, B. M. Balychev, P. A. Storozhenko, L. V. Ivankina and A. I. Gobumov, Inorg. Chim. Acta, 1989, 164, 211-220.

12 S. J. Lancaster, ChemSpider, 2003, 215, DOI: 10.1039/sp215.

13 N. A. Yakelis and R. G. Bergman, Organometallics, 2005, 24, 3579-3581.

14 T. J. Herrington, A. J. W. Thom, A. J. P. White and A. E. Ashley, Dalton Trans., 2012, 41, 9019-9022.

15 S. Toyota, M. Asakura, M. Ōki and F. Toda, Bull. Chem. Soc. Jpn., 2000, 73, 2357-2362.

16 N. Iwasa, S. Katao, J. Liu, M. Fujiki, Y. Furukawa and K. Nomura, Organometallics, 2009, 28, 2179-2187.

17 M. J. Walton, S. J. Lancaster and C. Redshaw, ChemCatChem, 2016, 6, 1892-1898 and references therein.

18 See Handbook of Ring Opening Polymerization, ed. P. Dubois, O. Coulembier and J.-M. Raquez, Wiley-VCH, 2009.

19 See for example: (a) P. J. A. Int Veld, E. M. Velner, P. Van de Witte, J. Hamhuis, P. J. Dijkstra and J. Feijen, J. Polym. Sci., Part A: Polym. Chem., 1997, 35, 219-226; (b) Y. Liu, W.-S. Dong, J.-Y. Liu and Y.-S. Li, Dalton Trans., 2014, 43, 2244-2251.

20 (a) M. H. Chisholm, J. C. Gallucci, H. Yin and H. Zhen, Inorg. Chem., 2005, 44, 4777-4785; (b) D. A. Walker, T. J. Woodman, D. L. Hughes and M. Bochmann, Organometallics, 2001, 20, 3772 .

21 APEX 2 \& SAINT software for CCD diffractometers, Bruker AXS Inc., Madison, USA, 2006-2014.

22 (a) G. M. Sheldrick, Acta Crystallogr., Sect. C: Struct. Chem., 2015, 71, 3-8; (b) G. M. Sheldrick, Acta Crystallogr., Sect. A: Found. Adv., 2015, 71, 3-8; (c) L. Palatinus and G. Chapuis, J. Appl. Crystallogr., 2007, 40, 786-790. 